\title{
TAX AMNESTY DARI PERSPEKTIF MASYARAKAT PAJAK
}

\author{
Nabila Istighfarin \\ Sekolah Tinggi Ilmu Ekonomi Indonesia (STIESIA) Surabaya \\ nabila.istighfarin@gmail.com \\ Fidiana \\ Sekolah Tinggi Ilmu Ekonomi Indonesia (STIESIA) Surabaya \\ fidiana@stiesia.ac.id
}

Received: $30-11-2017$

Revised: $08-03-2018$

Accepted: 19-04-2018

\section{ABSTRAK}

Otoritas pajak melakukan reformasi di bidang perpajakan, salah satunya melaui tax amnesty untuk meningkatkan kepatuhan pajak. Penulisan ini bertujuan untuk mengetahui implementasi tax amnesty. Penelitian ini menggunakan pendekatan kualitatif. Teknik pengumpulan data menggunakan teknik wawancara mendalam kepada informan penelitian yaitu otoritas pajak, wajib pajak, dan konsultan pajak. Data yang terkumpul dianalisis dengan membagi ke dalam tema-tema dan sub tema. Penelitian ini menemukan bahwa implementasi tax amnesty belum berjalan secara optimal karena belum adanya standarisasi informasi antar otoritas pajak yang satu dengan yang lainnya, KPP satu dengan yang lainnya, masih belum memadainya jumlah pegawai yang bertugas melayani tax amensty, kurangnya kualitas sistem antrian pelayanan tax amnesty, dan masih belum intensifnya sosialisasi tax amnesty untuk wajib pajak.

Kata Kunci: kepatuhan pajak; masyarakat pajak; tax amnesty.

\section{ABSTRACT}

Tax authority has done the reformation in the field of taxation, one of the reformation in taxations is tax amnesty to improve the tax compliance. The purpose of this research is to find out the implementation of tax amnesty from the perspective of tax public, meanwhile the way to achieve the goal of this research is carried out by conducting interview with several parties from the tax authorities, tax consultants, and the taxpayer. This research is qualitative and 11 informants in tax community perspective. The data collection technique has been carried out by using depth interview to the related parties. The data analysis data has been done by using data collection, verification, data reduction, and data presenting. The result of this research shows that the implementation of tax amnesty has not run well and optimal yet because it still has constrained problem i.e. the lack of standardization information among tax authorities one and anothers, and among one KPP to another in the implementation of tax amnesty, the numbers of employees at KPP has not adequate yet, the lack of quality of queuing system of tax amnesty services, and the socialization of tax amnesty for taxpayers has not been intesive yet.

Keywords: tax amnesty; tax compliance; tax community.

How to cite: Istighfarin, N., Fidiana. (2018). Tax Amnesty dari Perspektif Masyarakat Pajak. Akrual: Jurnal Akuntansi. 9 (2): 142-156.doi: http://dx.doi.org/10.26740/jaj.v9n2.p142-156

\section{PENDAHULUAN}

Pajak merupakan sumber penerimaan terbesar $(84,9 \%)$ negara untuk mendanai APBN
(Kementerian Keuangan, 2016). Peran pajak yang diharapkan sebagai satu-satunya sumber pendapatan, ternyata terdapat kendala kepatuhan 
wajib pajak sehingga penerimaan pajak tidak maksimal. Pemerintah akhirnya mengeluarkan kebijakan tax amnesty.

Kebijakan tax amnesty diharapkan akan memperbaiki masalah kepatuhan, memperbaiki database perpajakan di Indonesia, dan sekaligus mengurangi kebocoran pajak (Ngadiman dan Huslin, 2015; Pratiwi, 2016; Ragimun, 2014; dan Sari, 2005). Penerapan kebijakan pengampunan pajak atau lebih dikenal sebagai kebijakan tax amnesty diatur dalam Undangundang Republik Indonesia No.11 Tahun 2016. Pada tahap awal, pemerintah memperkirakan kebijakan tax amnesty ini akan berpotensi menyumbang tambahan penerimaan negara sebesar Rp100 triliun (Brodjonegoro, 2016). Tax amnesty seharusnya akan memberikan dampak positif yang luar biasa bagi struktur APBN ke depannya. Pengalaman di banyak negara sudah membukti-kan hal tersebut. Korea Selatan, Afrika Selatan dan India adalah contoh-contoh negara yang sukses menerapkan kebijakan tax amnesty (Bagiada dan Darmayasa, 2016). Namun ternyata, target tersebut tidak tercapai.

Pada tahun 1984 pemerintah pernah meluncurkan kebijakan tax amnesty. Dalam implementasinya, kebijakan tersebut dinilai tidak sukses. Hal ini salah satunya disebabkan oleh rendahnya respon wajib pajak. Oleh karena itu, pemerintah meresponnya dengan menerapkan modernisasi sistem perpajakan di Indonesia (Ragimun, 2014). Saat ini tax amnesty telah memasuki tahap ketiga. Tax amnesty periode I dinyatakan tidak terlalu sukses yang mana target penerimaan sebesar 165 triliun hanya dicapai sebesar 97,2 triliun atau $(58,9 \%)$ dari target penerimaan pajak (Nugroho, 2016).

Ketidakberhasilan tax amnesty ini memotivasi penulis untuk menggali hal-hal yang relevan dengan ketidaksuksesan tax amnesty. Oleh karena data tax amnesty tidak dipublikasi (bukan konsumsi publik), maka penulis berupaya menggali implementasi tax amnesty dari sudut pandang masyarakat pajak (otoritas pajak, konsultan pajak, dan wajib pajak) di wilayah Surabaya. Dalam penulisan ini menghasilkan gambaran pelaksanaan tax amnesty dari kacamata masyarakat pajak terkait motivasi, kendala dan tantangan serta hal teknis atas ketidaktercapaian tax amnesty.

Penelitian terdahulu yang berhubungan dengan tax amnesty diantaranya kajian oleh Bagiada dan Darmayasa (2016) bahwa tax amnesty menjadi kebijakan yang didasarkan oleh niat tulus (kama) untuk meningkatkan pendapatan negara dalam jangka pendek dan jangka panjang dengan memberikan tarif tebusan yang berlandaskan kebajikan (dharma) untuk menarik artha wajib pajak dari luar negeri ke dalam negeri. Hasil kebijakan tax amnesty diharapkan mampu mencerahkan hati seluruh wajib pajak demi mewujudkan kepatuhan sukarela untuk meningkatkan kesejahteraan masyarakat. Asih dan Chomsatu (2016) memberi gambaran motivasi masyarakat mengikuti tax amnesty melalui pertimbangan tarif. Penelitian-penelitian terdahulu belum memberi jawaban ketidak suksesan tax amnesty. Penelitian tersebut 
AKRUAL: Jurnal Akuntansi, volume 9, nomor 2, April 2018 (142-156)

umumnya berkutat mengingatkan otoritas bahwa tarif menjadi salah satu pertimbangan mematuhi pajak. Oleh karena itu, penelitian ini hendak mengisi gap riset mengapa tax amnesty tidak berhasil mencapai target atau tidak mampu meningkatkan penerimaan negara sebagaimana yang telah ditargetkan termasuk kendala-kendala pencapaian target.

\section{METODE PENELITIAN}

Untuk mencapai tujuan penulisan yang bersifat memperoleh gambaran fenomena tentang motivasi dan seputar perilaku masyarakat pajak tentang tax amnesty, maka studi ini menggunakan penulisan kualitatif. Penulisan kualitatif merupakan proses penulisan yang menghasilkan data deskriptif berupa kata-kata tertulis atau lisan dari orang-orang dan perilaku yang diamati (Moleong, 2007). Cara ini efektif untuk melukiskan secara sistematis fakta-fakta atau karakteristik populasi tertentu, dan bidang tertentu, baik berupa keadaan, permasalahan, sikap, pendapat, kondisi, prosedur atau sistem secara faktual dan cermat. Studi kasus umumnya digunakan untuk menjelaskan dan menggambarkan/mendeskripsikan serta memecahkan masalah (Soewadji, 2012:26).

Informan dipilih dengan menggunakan teknik convenience sampling yaitu 1) wajib pajak yang mengikuti tax amnesty; dan 2) bersedia meluangkan waktunya untuk memberikan informasi lengkap dan akurat. Sebagaimana diketahui secara umum, tidak semua masyarakat pajak bersedia memberikan informasi perpajakan, mereka menganggap pajak sebagai rahasia.

Penelitian ini menggunakan data primer. Data diperoleh secara langsung dari informan dapat berupa kalimat tertulis atau lisan, perilaku, fenomena, peristiwa-peristiwa, pengetahuan, yang ditemui penulis di Kantor Pelayanan Pajak. Data yang diperoleh penulis berupa hasil wawancara tidak terstruktur. Tahapan penyajian data dapat dijelaskan sebagai berikut (Miles dan Huberman, 1992) pertama, data yang diperoleh dari hasil wawancara di lapangan disalin dalam bentuk transkrip. Kedua, pengambilan keputusan atau verifikasi yaitu setelah meperoleh data yang dibutuhkan, maka akan ditentukan pola, model, dan tema yang sesuai dengan fokus penulisan. Ketiga, reduksi data dengan cara memilih hal pokok yang sesuai pada fokus penulisan. Keempat, penyajian data merupakan tersusunnya informasi yang memungkinkan adanya penarikan kesimpulan.

Tabel 1. Daftar Informan Penulisan

\begin{tabular}{ccll}
\hline No & \multicolumn{1}{c}{ Status } & \multicolumn{1}{c}{ Nama } & \multicolumn{1}{c}{ KPP } \\
\hline 1 & Otoritas & Bpk. Hary & Gubeng \\
& $\begin{array}{c}\text { Pajak } \\
2 \\
\text { Konsultan } \\
\text { Pajak }\end{array}$ & Bpk. Gondo & Genteng \\
& & Bpk.Basuki & Wonocolo \\
& & Ibu Indri & Mulyorejo \\
3 & Wajib & Ibu Arista & Sawahan \\
& Pajak & & \\
& & Ibu Sumariyati & Gubeng \\
& & Ibu Diyah & Sukomanunggal \\
& & Bpk. Winarto & Rungkut \\
& & Ibu Sari & Karangpilang \\
& & Bpk. & Wonocolo \\
& & Kurniawan & \\
& & Ibu Yuhana & Sukomanunggal \\
\hline
\end{tabular}

Sumber: data diolah penulis

Informan dalam penulisan ini disamarkan namanya (lihat tabel 1), bertujuan untuk 
menjaga kenyamanan dan bagian dari etika penulisan kualitatif.

\section{ANALISIS DAN PEMBAHASAN}

\section{Latar Belakang Implementasi Tax amnesty}

Pada dasarnya pemerintah mengeluarkan

kebijakan pengampunan pajak untuk memenuhi penerimaan jangka panjang serta jangka pendek. Tax amnesty dilakukan untuk memperbaiki perekonomian Indonesia khususnya. Hal ini sejalan dengan pandangan Ibu Indri (Konsultan Pajak) berpendapat bahwa:

"Kebijakan tax amnesty itu memang untuk saat ini diperlukan karena perekonomian Indonesia untuk saat ini lagi turun, jadi tax amnesty bisa dijadikan sebagai salah satu langkah awal untuk memperbaiki perekonomian Indonesia.”

Pendapat Ibu Indri lebih menekankan bahwa untuk kedepannnya adanya tax amnesty tahun ini akan sangat membantu upaya pemerintah memperbaiki kondisi perekonomian, pembangunan, mengurangi pengangguran, dan mengurangi kemiskinan. Asih dan Chomsatu (2016) juga menyatakan bahwa pertumbuhan ekonomi saat ini cenderung mengalami perlambatan penerimaan pajak berkurang dan berdampak pada ketersediaan likuiditas dalam negeri. Hal itu yang menjadi motif pemerintah mengeluarkan Undang-undang pengampunan pajak (tax amnesty) dengan diikuti dengan peraturan Menteri Keuangan 118/PMK.03/2016 tentang penerapan kebijakan dari Undangundang tersebut. Sedangkan pandangan berbeda disampaikan oleh Bapak Gondo selaku Konsultan Pajak mengenai tax amnesty bahwa:
"Kebijakan tax amnesty yaitu suatu kebijakan yang ditunjukkan kepada wajib pajak yang tidak jujur dalam melaporkan kewajiban perpajakannya, dengan tax amnesty ini adalah saat untuk bisa membuat kejujuran itu dengan tarif yang tidak terlalu mahal, dibandingkan dengan tarif normal yang sebesar 5\%."

Pandangan Bapak Gondo menguatkan temuan (Belkaoui, 2014; Darmayasa dan Aneswari, 2015) bahwa tax amnesty adalah suatu kebijakan yang ditujukan bagi wajib pajak yang selama ini lalai dalam melaporkan hartanya serta untuk meningkatkan kepatuhan sukarela berupa kesediaan melaporkan pajak secara benar, lengkap, dan jelas. Dari pendapat kedua informan tersebut, terlihat jelas bahwa penerapan kebijakan tax amnesty tidak hanya akan memperbaiki kondisi perekonomian di Indonesia saja, tapi mampu mendorong wajib pajak untuk mengungkapkan data atas harta atau kekayaan secara sukarela (voluntary disclousure). Hal itu tidak jauh berbeda dengan pernyataan yang disampaikan oleh Bapak Hary, Pegawai Seksi Pelayanan tax amnesty yang berada di KPP Surabaya bahwa tax amnesty lebih kepada pengungkapan seluruh harta wajib pajak:

"Tax amnesty itu mengungkapkan seluruh harta bisa apapun hartanya definisi harta itu sendiri adalah tambahan kemampuan ekonomis berupa asset tidak berwujud dan asset berwujud seperti contohnya rumah, tanah, kendaraan, uang tunai, dan sebagainya. Jadi definisi tax amnesty itu sendiri yaitu pengungkapan atas harta wajib pajak yang belum dilaporkan untuk tahun 2015 dan tahun sebelumnya."

Pandangan yang sama juga disampaikan

oleh Bapak Basuki sebagai Konsultan Pajak 
AKRUAL: Jurnal Akuntansi, volume 9, nomor 2, April 2018 (142-156)

mengenai tax amnesty adalah dengan cara melakukan pengungkapan harta sebagai berikut:

"Kewenangan kebijakan tax amnesty itu kebijakan yang bagus ya karena sebagai sarana untuk bisa memasukkan harta yang belum dilaporkan, jadi dengan mengikuti tax amnesty tidak akan diusut asal muasalnya yang belum tercantum di SPT pribadi maupun di SPT Badan. Dengan itu maka dimasukkan dengan tidak melihat asal-usul harta tersebut dan juga berapa besar nominal harta tersebut dan juga berapa jumlah uang tebusan yang dibayarkan."

Informan diatas sepakat dan paham bahwa tax amnesty adalah pengampunan pajak atas penghapusan pajak yang terutang, tidak dikenai sanksi administrasi perpajakan dan sanksi pidana dibidang perpajakan, dengan cara mengungkapkan seluruh harta atau kekayaan yang belum dilaporkan dan membayar uang tebusan sebesar tarif yang berlaku. Data pengungkapan harta yang berasal dari wajib pajak sangat berarti bagi aparat pajak.

Kedepan, dengan tercatatnya data harta atau kekayaan wajib pajak dalam sistem administrasi perpajakan melalui program tax amnesty, maka selanjutnya sulit bagi wajib pajak untuk menghindar dari kewajiban perpajakan di masa yang akan datang (Darussalam, 2011).

\section{Motivasi 1: Penghindaran Risiko}

Lim (2011) mendefinisikan tax avoidance sebagai penghematan pajak yang timbul dengan memanfaatkan ketentuan perpajakan yang dilakukan secara legal untuk meminimalkan kewajiban pajak. Upaya ini bertujuan untuk memperoleh manfaat pajak dengan cara yang tidak melanggar undang-undang perpajakan.
Motivasi ini dapat dikaitkan dengan tax amnesty, bahwa wajib pajak untuk mengikuti kebijakan ini berkaitan dengan penghindaran pajak (tax avoidance) dan sanksi administrasi perpajakan (Suandy, 2008). Motivasi ini ditemukan pada wajib pajak di salah satu KPP di Surabaya (Ibu Arista) sebagai berikut:

"Saya ikut ya karena menghindari resiko terkena pemeriksaan untuk periode tahun 2015 kebawah dikarenakan pengalaman dari temanteman yang terkena pemeriksaan membutuhkan banyak waktu untuk menemukan data yang diminta KPP dan ditahun-tahun sebelumnya saya juga ada beberapa harta yang menurut saya kecil atau tidak material yang tidak saya laporkan."

Tidak jauh berbeda dengan pandanganpandangan tersebut, ternyata wajib pajak yang lain juga menegaskan motivasi penghindaran resiko wajib pajak mengikuti tax amnesty, seperti disampaikan oleh Ibu Sumariyati dan Ibu Indri:

"Saya ikut tax amnesty memanfaatkan program pemerintah yang memberikan kompensasi bagi wajib pajak yang selama ini belum melaporkan atau kurang melaporkan harta yang dimiliki. Selain itu untuk memanfaatkan fasilitas bebas pemeriksaan selama 5 tahun yang diberikan pemerintah apabila wajib pajak mengikuti program tax amnesty.

Biasanya tujuan yang melatarbelakangi wajib pajak mengikuti tax amnesty yaitu manfaat yang akan diterima wajib pajak. Manfaatnya salah satunya adalah bahwa wajib pajak tidak akan diperiksa, karena di undang-undang sudah dituangkan tentang manfaat yang akan diperoleh wajib pajak apabila berpartisipasi dalam kebijakan tax amnesty."

Apa yang disampaikan Ibu Sumariyati dan Ibu Indri diatas merupakan pernyataan yang menekankan bahwa motivasi wajib pajak mengikuti kebijakan tax amnesty ini didasarkan oleh manfaat yang diberikan oleh Direktorat 
Jenderal pajak, apabila wajib pajak mengikuti kebijakan tax amnesty ini berupa bebas dari tindakan pemeriksaan pajak dan penghapusan sanksi administrasi perpajakan untuk tahun pajak sebelumnya.

Prinsip seperti ini dapat dijelaskan melalui teori pertukaran seperti pada tulisan Fidiana (2015:264) yang mengaitkan perilaku penghindaran wajib pajak dengan sistem imbalan atau kompensasi yang akan diterima wajib pajak berupa manfaat bebas tindakan pemeriksaan pajak apabila wajib pajak mengikuti program kebijakan tax amnesty sebagai imbalan atas pengorbanan mereka membayar pajak.

Pemeriksaan Pajak adalah serangkaian kegiatan untuk mencari, mengumpulkan, mengolah data dan keterangan lainnya, untuk menguji kepatuhan pemenuhan kewajiban perpajakan serta untuk tujuan lain, dalam rangka melaksanakan ketentuan peraturan perundangundangan perpajakan (Waluyo dan Ilyas, 2001:10). Sementara Hidayat (2002) mendeskripsi pemeriksaan pajak sampai saat ini masih dipandang sebagai sosok yang menakutkan yang dirasakan wajib pajak ketika berurusan dengan masalah pajak. Sebab dari itu, Dengan adanya bebas dari tindakan pemeriksaan pajak membuat wajib pajak tergiur untuk memanfaatkan program tax amnesty. Hal ini menandaskan mulai tumbuhnya rasa kepatuhan secara sukarela wajib pajak untuk melaporkan kewajiban perpajakannya. Terbukti itu tertuang pada undang-undang pengampunan pajak mengenai bebas dari tindakan pemeriksaan pajak, dalam hal ini wajib pajak telah dijamin dalam undang-undang tersebut tidak akan dilakukan pemeriksaan pajak, pemeriksaan bukti permulaan dan penyidikan atas kesalahan pajak di masa lalu dan kedepannya setelah tax amnesty berakhir diharapkan menjadi wajib pajak yang patuh pada peraturan perundang-undangan perpajakan.

\section{Motivasi 2: Pola Pikir Ekonomis/Bisnis}

Wajib pajak memperhitungkan tarif terendah, antara ikut tax amnesty atau lapor dengan denda di SPT. Inilah motivasi mereka ikut tax amnesty Hal tersebut serupa dengan penulisan Fidiana (2014) menyatakan bahwa Rational economic man murni yang ditandai dengan pola pikir matematis dalam urusan perpajakan yang mana tax amnesty dimaksudkan untuk memaksimalkan manfaat dan menghindari biaya lainnya. Wajib pajak cenderung tertarik dengan tarif pajak yang rendah dibandingkan dengan tarif pajak yang tinggi, dan ini ditawarkan oleh tax amnesty. Bagiada dan Darmayasa (2016:19) menjelaskan bahwa dengan adanya tarif tebusan pengampunan pajak, relatif memikat wajib pajak sehingga mendorong mereka untuk memanfaatkan tax amnesty. Hal ini tidak jauh berbeda dengan apa yang disampaikan oleh Ibu Diyah sebagai wajib pajak motivasi mengikuti tax amnesty sebagai berikut:

"Saya ikut tax amnesty karena menurut saya tarif uang tebusan yang cukup menarik ya sebesar 2\% sampai dengan 5\%, tarif itu kan masih dibawah tarif normal jadi saya ingin ikut." 
AKRUAL: Jurnal Akuntansi, volume 9, nomor 2, April 2018 (142-156)

Pandangan yang sama juga disampaikan

oleh Bapak Basuki selaku Konsultan pajak berpendapat bahwa:

"Sebetulnya dengan adanya tarif tebusan segitu ya cukup menarik ya, karena kalau dibandingkan tarif $\mathrm{PPh}$ sebesar 5\%, 15\%, dan $25 \%$ sedangkan tarif tax amnesty yang hanya $2 \%, 3 \%$, dan $5 \%$ berarti kan masih dibawah tarif normal $\mathrm{PPh}$ jadi sangat kecil dibandingkan di SPT normal."

Yang disampaikan Ibu Diyah dan

Bapak Basuki menyatakan bahwa terkait pola pikir matematis wajib pajak melalui pemanfaatan tarif tebusan yang rendah, sehingga mendapatkan manfaat pajak. Dengan adanya tarif tebusan yang diberikan pemerintah dengan tarif yang lebih rendah, itu akan menumbuhkan motivasi wajib pajak berpartisipasi dalam program amnesti pajak. Hal itu sesuai pada penulisan Asih dan Chomsatu (2016:340) tarif uang tebusan yang diberikan dalam amnesti pajak lebih rendah dibandingkan dengan tarif pajak pada umumnya, diharapkan dengan tarif yang rendah keikutsertaan program amnesti pajak semakin meningkat. Karena wajib pajak pada dasarnya menghindari tarif pajak yang tinggi namun terutang tarif pajak yang lebih rendah, dapat disimpulkan bahwa semakin tinggi tarif pajak yang dikenakan tinggi pula motivasi wajib pajak untuk melakukan penghindaran pajak (Herlina dan Toly, 2013).

Motivasi berbeda terkait implementasi tax amnety didasarkan pada penghindaran sanksi admnistrasi. Herlina dan Toly (2013) Sanksi admnistrasi tersebut dapat berupa denda dan sanksi bunga. Hal ini yang menjadikan motivasi wajib pajak mengikuti tax amnesty ini, karena ingin melakukan kewajiban perpajakannya secara benar agar terhindar dari denda dan sanksi bunga. Tapi ternyata tidak jauh berbeda dengan pernyataan yang disampaikan Bapak Winarto motivasi mengikuti tax amnesty dikarenakan adanya sanksi bunga bila tidak mengikuti tax amnesty berikut:

"Saya ikut tax amnesty kan kalau misalkan saya $g a$ ikut saya dikenakan sanksi sebesar tarif $\mathrm{PPh}$ pribadi yang berlaku dan sanksi bunga sebesar $2 \%$ perbulan maksimal 24 bulan atau maksimal $48 \%$. Memang sayang banget tapi dilihat resikonya sangat besar dan sudah dijadikan dasar Undang-undang juga kan."

Hal itu juga diperkuat oleh pernyataan Bapak Hary dari Pegawai Seksi Pelayanan Tax amnesty di KPP yang berada di Surabaya bahwa

"Apabila wajib pajak yang mengikuti tax amnesty dan dikemudian hari ternyata ditemukan ada harta yang tidak diungkapkan akan dikenakan sanksi denda dengan tarif yang berlaku dan ditambah sanksi denda sebesar 200 $\%$. Sedangkan wajib pajak yang tidak ikut tax amnesty apabila ditemukan harta yang belum dilaporkan didalam pembetulan SPT Tahunan, maka temuan harta tersebut akan dikenakan sanksi denda dengan tarif yang berlaku dan ditambahkan sanksi bunga sebesar $2 \%$ perbulan maksimal kurun waktu 24 bulan."

Dari pernyataan yang disampaikan oleh Bapak Winarto dan Bapak Hary menyatakan bahwa wajib pajak termotivasi mengikuti tax amnesty, dikarenakan wajib pajak lebih kepada menghindari sanksi administrasi perpajakan berupa sanksi bunga dan denda. Wajib pajak cenderung akan patuh melakukan kewajiban perpajakannya apabila sudah dikenakan sanksi tegas atas segala tindakan tidak jujur dalam

Copyright@2018 AKRUAL: Jurnal Akuntansi 
menyampaikan kewajiban perpajakannya.

Rahayu dan Suhayati (2010:87) pengertian sanksi administrasi perpajakan merupakan pembayaran kerugian kepada negara khususnya yang berupa denda yang dikenakan terhadap pelanggaran kewajiban pelaporan, bunga yang dikenakan terhadap pelanggaran kewajiban pembayaran pajak, dan kenaikan berupa kenaikan jumlah pajak yang harus dibayar, terhadap pelanggaran berkaitan dengan kewajiban yang diatur dalam ketentuan material.

Devano dan Rahayu (2006:112) bahwa pelaksanaan sanksi perpajakan diterapkan sebagai akibat tidak terpenuhinya kewajiban perpajakan oleh wajib pajak sebagaimana yang telah diatur dalam undang-undang perpajakan. Pelaksanaan sanksi kepada wajib pajak dapat menyebabkan terpenuhinya kewajiban perpajakan oleh wajib pajak sehingga dapat meningkatkan kepatuhan wajib pajak. Wajib pajak akan patuh (karena tekanan) karena mereka memikirkan adanya sanksi berat berupa denda akibat tindakan illegal dalam usahanya menyelundupkan pajak.

Sebagaiamana diketahui suatu kebijakan berupa pengenaan sanksi dapat dipergunakan untuk dua tujuan utama, yang pertama adalah untuk mendidik dan yang kedua adalah untuk menghukum. Mendidik dimaksudkan agar mereka yang dikenakan sanksi akan menjadi lebih baik dan lebih mengetahui hak dan kewajibannya sehingga tidak lagi melakukan kesalahan yang sama. Maksud yang kedua adalah untuk menghukum sehingga pihak yang terhukum akan menjadi jera dan tidak lagi melakukan kesalahan yang sama (Zahidah, 2010:15).

Jadi dapat disimpulkan pengenaan sanksi administrasi perpajakan merupakan cara otoritas pajak agar wajib pajak patuh dan tidak melakukan tindakan curang dalam memenuhi kewajiban perpajakannya. Dengan adanya sanksi berat, diharapkan wajib pajak akan jera dan memiliki motivasi untuk ikut serta menyukseskan progam kebijakan tax amnesty.

\section{Kendala dan Tantangan Tax amnesty}

Berdasarkan hasil wawancara penulis mengenai kajian empiris yang ada dilapangan menunjukkan bahwa implementasi tax amnesty ini menghadapi beberapa kendala yang pertama masalah sosialisasi pajak. Kegiatan sosialisasi pajak ini sangat penting karena pengetahuan dan wawasan wajib pajak akan sistem dan peraturan perpajakan yang berlaku saat ini masih sangat kurang. Kurangnya pengetahuan dan pemahaman wajib pajak terhadap pengisian formulir tax amnesty dan penyiapan dokumen pendukung amnesti ini yang menjadikan kendala wajib pajak mengikuti tax amnesty. Berikut adalah pernyataan dari Ibu Arista dan Ibu Diyah selaku wajib pajak yang ada di Surabaya tentang kendala dan tantangan implementasi tax amnesty

"Kendala saya ikut tax amnesty, saya agak kebingungan dalam pengisian kolom-kolom yang disediakan oleh KPP terutama pada bagian kolom kode harta yang membuat saya sedikit kebingungan."

"Saya agak bingung ya untuk pengisian formulir surat pernyataan harta dan pada kode harta dan pada saat saya lapor terdapat kendala formulir surat pernyataan harta saya 
AKRUAL: Jurnal Akuntansi, volume 9, nomor 2, April 2018 (142-156)

tidak terbaca pada sistem komputerisasi pajak yang membuat harus diedit-edit ulang dan memakan waktu yang cukup lama sekali."

Sedangkan pendapat yang sama juga dikemukakan Ibu Yuhana sebagai wajib pajak dan Bapak Basuki sebagai konsultan pajak mengenai kendala dan hambatan saat mengikuti tax amnesty:

"Saya kesulitan saat mengisi form tax amnesty karena cara pengisiannya berbeda dengan pada SPT biasanya."

"Kesulitan dalam penyiapan dokumen pendukung untuk tax amnesty, misalnya harta kepemilikan rumah yang belum ikut tax amnesty tapi bukti kepemilikannya sertifikatnya rumah itu milik siapa ternyata milik sendiri ataupun masih milik orang lain bisa dibilang status harta tersebut bagaimana. Sejauh ini kendala yang saya temui ya dalam penyiapan dokumen pendukung seperti itu."

Pendapat informan diatas menekankan bahwa wajib pajak masih menemui kesulitan dalam mengisi surat permohonan tax amnesty dan kurangnya pemahaman wajib pajak terkait tax amnesty. Hal tersebut bisa dipahami karena masih minimnya sosialisasi terhadap wajib pajak, karena terdapat pengisian kolom harta yang sedikit rumit dan apalagi terdapat kendala dalam penyiapan bukti-bukti pendukung harta, itu yang membuat wajib pajak masih merasa kebingungan.

Hal ini dibutuhkan peran penting DJP untuk memberikan pemahaman yang jelas dengan cara sosialaisasi secara menyeluruh kepada wajib pajak, agar kedepannya wajib pajak lebih paham dan memperoleh kemudahan atas pengisian formulir surat pernyataan harta tax amnesty. Wurianti (2016:6) Sosialisasi adalah suatu konsep umum yang dimaknakan 150 sebagai proses dimana kita belajar melalui interaksi dengan orang lain, tentang cara berfikir merasakan dan bertindak dimana kesemuanya itu merupakan hal-hal yang sangat penting dalam menghasilkan partisipasi sosial yang efektif. Sosialisasi pajak yang diberikan kepada masyarakat dimaksudkan untuk memberikan pengetahuan dan wawasan kepada wajib pajak mengenai kebijakan perpajakan (Winerungan, 2013).

Perlunya melakukan strategi sosialisasi secara jelas agar tidak membuat bingung wajib pajak, dengan penafsiran yang berbeda dari petugas satu dengan petugas yang lainnya mengenai penjelasan tax amnesty. Upaya sosialisasi secara bekelanjutan untuk memberikan pengertian, informasi, dan pembinaan kepada masyarakat pada umumnya dan wajib pajak pada khususnya mengenai kebijakan perpajakan. Bentuk sosialisasi perpajakan bisa dilakukan dengan penyuluhan. kegiatan penyuluhan pajak memiliki andil besar dalam menyukseskan sosialisasi pajak ke seluruh wajib pajak.

Sedangkan kendala yang lain tentang masalah tidak adanya standarisasi informasi tax amnesty antar otoritas pajak. Hal ini dibuktikan adanya informasi yang berbeda yang diterima wajib pajak pada saat mengikuti tax amnesty yang disampaikan oleh otoritas pajak, dan juga kurangnya pemahaman otoritas pajak tentang prosedur dan pedoman teknis kebijakan tax amnesty secara komprehensip untuk disampaikan kepada wajib pajak. Berikut ini pernyataan dari Ibu Yuhana dan Ibu Diyah sebagai wajib

Copyright@2018 AKRUAL: Jurnal Akuntansi 
pajak yang ada di Surabaya mengenai kendala dan tantangan yang dihadapin dalam implementasi tax amnesty:

"Saya kurang puas atas segi pelayanan tax amnesty, karena bagian penerima juga masih kurang paham dengan pengisian tax amnesty mereka terkadang masih bertanya-tanya dengan rekan kerja disampingnya entah karena memang tax amnesty ini peraturan baru atau karena cara pengisiannya yang rumit tapi seharusnya bagian pajak harus paham betul dengan program pengampunan pajak terbaru ini agar masyarakat pun juga puas dengan pelayanannya."

"Saya agak tidak puas ya, karena pihak KPP khususnya bagian penerimaan kurang cekatan dan masih saling bertanya kepada pihak bagian penerimaan lain, menurut saya mungkin ini peraturan baru, sehingga petugas belum paham betul tentang kebijakan yang baru ini."

Hal yang sama juga disampaikan oleh Ibu Sumariyati terkait kendala dan hambatan implementasi tax amnesty yang berada di KPP Surabaya:

"Petugasnya terkadang kurang paham betul sehingga sering tanya antar sesama petugas sehingga saya harus menunggu lama. Seharusnya juga lebih ditekankan dengan menambah pengetahuan petugas tax amnesty lebih dalam, agar tidak saling tanya antar petugas sehingga tidak membutuhkan waktu lama dalam pengecekan."

Menilik dari pernyataan diatas bahwa dari otoritas pajak belum siap mengenai kebijakan tax amnesty, hal ini dibuktikan kurangnya pemahaman otoritas pajak mengenai kebijakan tax amnesty untuk disampaikan kepada wajib pajak dan adanya perbedaan penafsiran antara petugas yang satu dan petugas yang lain terkait dengan penjelasan tentang tax amnesty yang akan disampaikan kepada wajib pajak. Penyebabnya, pemahaman petugas berbeda ketika menerima instruksi atau arahan dari atasannya.

Seharusnya otoritas pajak memberikan pemahaman yang jelas kepada wajib pajak, agar tidak membuat wajib pajak menunggu lama untuk memperoleh informasi tentang prosedur dan teknik penyampaiana pengampuanan pajak. Kedepannya kualitas pelayanan yang diberikan Kantor Pelayanan Pajak pada program tax amnesty yang sedang dijalankan yang diharapkan akan meningkatkan motivasi wajib pajak ikutserta dalam mensukseskan kebijakan ini.

Kendala yang kedua terkait masalah birokrasi pajak. Menurut Fidiana (2014) banyak wajib pajak masih mengeluhkan rumitnya birokrasi pajak. Wajib pajak tidak hanya direpoti dengan menghitung dan membayar pajak, tapi juga dipersulit dengan media laporan pajak, yaitu formulir surat pernyataan amnesti pajak. Kendala birokrasi perpajakan ini cenderung penyampaian informasinya sudah benar kepada wajib pajak, tapi wajib pajak masih terkendala rumitnya pengisian form amnesti yang membuat wajib pajak harus beberapa kali kembali lagi ke KPP untuk melengkapi dokumen-dokumen amnesti pajak. Berikut ini pernyataan Ibu Sumariyati dan Bapak Winarto sebagai wajib pajak terkait kendala dan tantangan yang dihadapi:

"Pelayanan tax amnesty kurang memuaskan karena petugasnya sedikit menyulitkan wajib pajak dengan kelengkapan dokumen sehingga saya harus bolak-balik ke KPP." 
AKRUAL: Jurnal Akuntansi, volume 9, nomor 2, April 2018 (142-156)

"Saya masukin data lapor tax amnesty sudah kembali tiga kali kalau gak empat kali revisi data, datanya masih kurang, dan datanya masih salah ini waktunya juga sangat mepet sekali."

Hal yang sama juga disampaikan oleh Ibu

Sari kendala dan tantangan saat melaporkan tax amnesty:

"Penafsiran peraturan tax amnesty harus benar-benar disosialisasikan dengan sejelasjelasnya kepada petugas sehingga tidak ada lagi penafsiran yang berbeda antara KPP satu dengan lainnya, Kanwil satu dengan kawil lainnya, dan petugas satu dengan petugas lainnya. Informasi yang salah atau penafsiran yang berbeda sangat merepotkan wajib pajaknya sehingga harus bolak-balik ke KPP / Kanwil."

Apa yang disampaikan wajib pajak mengenai kendala birokrasi pajak yang dihadapi dalam mengikuti program amnesti pajak lebih menekankan pada aspek teknis, yaitu kurang efektifnya informasi yang disampaikan otoritas pajak kepada wajib pajak. hal ini membuktikan wajib pajak masih harus bolak-balik ke KPP untuk melengkapi berkas pengampunan pajak yang kurang ataupun masih adanya kesalahan pengisian. Hal ini yang seharusnya kebijakan ini menjadi efektif tapi menjadi tidak efisien karena masih adanya kendala teknis dilapangan.

Kendala yang selanjutnya yang dihadapi wajib pajak terkait masalah sistem antrian yang lama, dan kurangnya sumber daya manusia yang berada di Kantor Pelayanan Pajak ini menyebabkan tidak efisiennya pelayanan tax amnesty yang ditunjukkan untuk memberikan kemudahan dan kenyamanan wajib pajak dalam berpartisipasi dalam program amnesti pajak. hal ini dibuktikan oleh pendapat Ibu Sari mengenai kendala dan tantangan mengikuti tax amnesty:
"Saya kurang puas atas sistem antrian yang begitu lama sekali, memakan waktu hingga seharian lamanya saya menunggu data saya bisa diterima oleh petugas pajak."

Tidak jauh berbeda dengan pandangan tersebut berikut pernyataan Bapak Kurniawan sebagai wajib pajak yang ada di KPP Surabaya mengenai kendala dan tantangan mengikuti tax amnesty:

"Saya datang ke KPP jam setengah 6 pagi baru dilayani sekitar jam 4 sore. antrian yang menumpuk dan menunggu lama itu sangat melelahkan sekali, dari memasukkan data mulai pagi hari manggilnya lama kemudian dipanggil ada masalah data lama lagi."

"Seharusnya disediakan sistem antrian yang lebih baik lagi, kemudian petugas pajaknya dibuat lebih banyak orang yang mengerjakannya dan petugas penulis tax amnesty dibuat lebih banyak orang lagi agar antriannya lebih cepat dan tidak menunggu lama."

Sedangkan pendapatan yang sama dikemukan Ibu Sumariyati sebagai wajib pajak dan Ibu Indri selaku konsultan pajak mengenai kendala dan tantangan saat mengikuti tax amnesty:

"Saya berharap agar petugas tax amnesty lebih ditambahkan lagi agar pelayanannya cepat dan tidak sampai membuat saya menunggu lama."

"Kedepannnya mungkin tax amnesty mungkin dari segi teknis bisa diperbaiki lagi masalah antrian."

Apa yang disampaikan informan diatas menyatakan bahwa kurang efektifnya kualitas pelayanan antrian kebijakan tax amnesty dan serta kurangnya sumber daya yang ada dilapangan menyebabkan wajib pajak yang mengikuti tax amnesty ini merasa terkendala dengan pelayanan yang diberikan Kantor Pelayanan Pajak. Pelayanan tax amnesty yang 
diberikan kepada wajib pajak merupakan pelayanan publik yang lebih diarahkan sebagai suatu cara pemenuhan kebutuhan masyarakat dalam rangka pelaksanaan peraturan perundangundangan yang berlaku (Mutia, 2014).

Arum (2012) menyarankan kualitas pelayanan pajak harus ditingkatkan lagi oleh otoritas pajak. Pelayanan yang baik akan memberikan kenyamanan dan kemudahan dalam sistem informasi perpajakan termasuk dalam segi kualitas pelayanan perpajakan. Demikian pula cara pandang hubungan psikologi wajib pajak dengan otoritas pajak pada skema pertukaran (exchange theory). Menurut skema ini kepatuhan sukarela dapat diciptakan jika wajib pajak memperoleh utilitas berupa layanan publik yang memuaskan atas pembayaran pajaknya (Fidiana, 2015). Dalam hal ini Otoritas pajak dituntut menciptakan fasilitas pajak dan sistem administrasi perpajakan yang mudah dan sederhana serta kesediaan melayani wajib pajak dengan ramah, jujur dan efisien sehingga akan timbul rasa percaya diri dari otoritas pajak.

Kedepannnya untuk diperbaiki lagi masalah kualitas pelayanan sistem antrian tax amnesty dan selain itu juga perlunya peningkatan sumber daya manusia (SDM) yang berada di Kantor Pelayanan Pajak, terlebih lagi agar wajib pajak merasakan kepuasan atas pelayanan tax amnesty. Menurut Wurianti (2016:6) pelayanan perpajakan dibentuk oleh dimensi kualitas sumber daya manusia (SDM), ketentuan perpajakan dan sistem informasi perpajakan. Standar kualitas pelayanan prima kepada masyarakat wajib pajak akan terpenuhi bilamana SDM melakukan tugasnya secara profesional, disiplin, dan transparan.

Pelayanan yang baik merupakan salah satu faktor penting dalam menciptakan kepuasan kepada wajib pajak. Ismail (2016) menyatakan bahwa untuk kualitas pelayanan pajak di KPP agar terus meningkatkan kecepatan proses pelayanan, dengan cara memperbaiki semua fasilitas penunjang yang ada seperti mesin antrian dan komputer yang digunakan untuk melayani wajib pajak, dan jangan sampai ada lagi gangguan teknis yang dapat menguras energi dan menghabiskan waktu petugas. Seperti masalah soft copy WP yang tidak dapat di-copy ke hard disc KPP. Hal tersebut agar sesuai dengan kebutuhan wajib pajak sehingga wajib pajak merasa nyaman dan memperoleh kemudahan dalam menyampaikan kewajiban perpajakannya.

\section{KESIMPULAN}

Berdasarkan hasil riset yang dilakukan selama 14 hari, penulisan ini menyimpulkan hasil temuan-temuan sebagai berikut: pertama, kurangnya standarisasi informasi yang sama antar otoritas pajak yang satu dengan yang lain, dan antara KPP satu dengan yang lainnya dalam pelaksanaan implementasi tax amnesty. Hal tersebut menyebabkan wajib pajak bingung dalam menerima informasi untuk keikutsertaan penyampaian tax amnesty. Kedua, masih belum memadainya jumlah pegawai di KPP yang ada di Surabaya yang dalam pengalokasinya sangat 
AKRUAL: Jurnal Akuntansi, volume 9, nomor 2, April 2018 (142-156)

kurang dan terbatas jumlah pegawai. Sehingga

hal tersebut menyebabkan tidak efektifnya pelayanan dalam implementasi tax amnesty. Ketiga, pelaksanaan implementasi tax amnesty saat ini belum berjalan dengan baik karena kurangnya ketersedian sarana dan prasana teknologi informasi dan komunikasi, seperti masalah komputer, masalah sistem antrian tax amnesty, dan lain sebagainya di nilai kurang memadai. Hal tersebut dikarenakan masih terbatasnya sarana dan prasarana yang ada di Kantor Pelayanan Pajak dan masih kurang memadainya sistem antrian untuk pelayanan tax amnesty. Keempat, pelaksanaan sosialisasi yang kurang intensif dan tidak berkelanjutan yang di lakukan oleh KPP di Surabaya. Hal ini dibuktikan bahwa masyarakat/wajib pajak masih terkendala masalah rumitnya birokrasi pajak seperti masih rumitnya pengisian formulir pernyataan tax amnesty dan penyiapan dokumen pendukung. Wajib pajak belum mengetahui dan memperoleh informasi yang cukup baik mengenai proses pelaksanaan tax amnesty.

Berdasarkan dari hasil evaluasi dan penulisan yang dilakukan dengan memperhatikan simpulan diatas, pada penulisan ini ada yang tidak bisa dicapai yaitu ada beberapa terkendala keterbatasan dan kerahasian informasi, maka saran untuk penulisan selanjutnya disarankan sebagai berikut: (1) melakukan peningkatan kualitas sumber daya manusia yang cepat, tanggap, dan berkompeten dalam memberikan pelayanan perpajakan berkaitan dengan pelaksanaan implementasi tax amnesty; (2) ditambahkan lagi jumlah pegawai 154 di KPP Pratama yang ada di Surabaya, khususnya pada bagian seski pelayanan dan penulis tax amnesty. Hal itu dilakukan agar pelaksanaan tax amnesty dapat berjalan dengan baik dan dapat meningkatkan pelayanan tax amnesty bagi masyarakat/wajib pajak; (3) perlunya perbaikan mengenai ketersedian sarana dan prasarana yang ada di KPP di Surabaya dalam rangka meningkatkan pelayanan kepada wajib pajak, agar proses pelayanan tax amnesty dilakukan dapat lebih efektif dan efisien serta lebih optimal lagi; (4) perlunya peningkatan standar informasi yang sama antar otoritas pajak yang satu dengan yang lainnya, dan antar KPP satu dengan yang lainnya agar pelaksanaan tax amnesty tidak membuat wajib pajak bingung dalam penyampaian informasi yang diterima; (5) sebaiknya dilakukan peningkatan kualitas pelayanan tax amnesty yang lebih cepat dan efisien sehingga masyarakat/wajib pajak tidak perlu mengantri terlalu lama pada saat pelaporan tax amnesty; (6) dilakukannya lagi sosialisasi yang lebih intensif dan berkelanjutan oleh Kantor Pelayanan Pajak yang ada di Surabaya kepada masyarakat/wajib pajak mengenai prosedur dan teknik penyampaian program tax amnesty. Hal ini dilakukan dengan cara memberikan seminar atau penyuluhan kepada masyarakat/wajib pajak mengenai cara pengisian penyampain tax amnesty. 


\section{DAFTAR PUSTAKA}

Arum, H. P. (2012). Pengaruh kesadaran wajib pajak, pelayanan fiskus, dan sanksi pajak terhadap kepatuhan wajib pajak orang pribadi yang melakukan kegiatan usaha dan pekerjaan bebas (studi di wilayah $\mathrm{kpp}$ pratama cilacap) (Doctoral dissertation, Fakultas Ekonomika dan Bisnis).

Chomsatu, Y., \& Asih, S. (2016). Pengaruh Prinsip Keadilan Dan Struktur Tarif Pajak Terhadap Keikutsertaan Program Amnesti Pajak. In Seminar Nasional Fakultas Ekonomi Uniba Surakarta (Vol. 2, No. 1, Pp. 338-347).

Bagiada, I. M., \& Darmayasa, I. N. (2016). Tax amnesty Upaya Membangun Kepatuhan Sukarela. Artikel disajikan dalam Simposium Nasional Akuntansi Vokasi V Makassar, 12-24 Mei 2016: 1-24.

Riahi-Belkaoui, A. (2004). Relationship between tax compliance internationally and selected determinants of tax morale. Journal of International Accounting, Auditing and Taxation, 13(2), 135-143. doi:10.1016/j. intaccaudtax.2004.09.001

Brodjonegoro, B. (2016). Wawancara Eksklusif Menteri Keuangan: Kebijakan Tax Amnesty Tahun 2016. Diunduh tanggal 23 September 2016, http://www.pajak.go.id/.

Darussalam, D. (2011). Mendongkrak Pajak dan Underground Economy. Investor Daily. Jakarta.

Darmayasa, I. N., \& Aneswari, Y. R. (2015). The Ethical Practice of Tax Consultant Based on Local Culture. Procedia - Social and Behavioral Sciences, 211, 142-148. doi:10.1016/j.sbspro.2015.11.021

Devano, S., \& Rahayu, S. K. (2006). Perpajakan: Konsep, Teori, dan Isu. Jakarta: Kencana.

Fidiana, F. 2014. Memperbarui Kesadaran dan Kepatuhan Berakuntansi, Berpajak, dan Berzakat. Disertasi. Program Doctor Universitas Brawijaya. Malang. . 2014. Eman dan Iman: Dualisme Kesadaran dan Kepatuhan. Artikel disajikan dalam Simposium Nasional Akuntansi XVII Mataram. 24-27 September: 1-23.
(2015). Kepatuhan Pajak Dalam Perspektif Neo Ashabiyah. EKUITAS (Jurnal Ekonomi dan Keuangan). Vol. 19 No. 2, p. 260-275.

Herlina, H., \& Toly, A. A. (2014). Faktor-Faktor Yang Mempengaruhi Perencanaan Wajib Pajak Di Surabaya. Tax \& Accounting Review, 3(2), 135.

Hidayat, N. (2002). Persiapan Wajib Pajak dalam Menghadapi Pemeriksaan Pajak. Jurnal Perpajakan Indonesia. Vol.1, No. 12, p. 16-19.

Ismail, H. (2016). Pendampingan WP UMKM dalam Program Amnesti Pajak.

Diunduh tanggal 2 Januari 2017, http://www.beritasatu.com/.

Kementrian Keuangan. (2016). Media Keuangan Transparansi Informasi Kebijkan Fiskal. Edisi April 2016. DJPK. Jakarta.

Lim, Y. (2011). Tax avoidance, cost of debt and shareholder activism: Evidence from Korea. Journal of Banking \& Finance, 35(2), 456470. doi:10.1016/j.jbankfin.2010.08.021

Miles, M. B., \& Huberman, A. M. (1992). Analisis data kualitatif.

Moleong, L. J. (2007). Metodologi Penelitian Kualitatif. Edisi Revisi. Bandung: PT. Remaja Rosdakary Offset. ISBN 979-514051-5.

Mutia, S. P. T. (2014). Pengaruh Sanksi Perpajakan, Kesadaran Perpajakan, Pelayanan Fiskus, Dan Tingkat Pemahaman Terhadap Kepatuhan Wajib Pajak Orang Pribadi (Studi Empiris pada Wajib Pajak Orang Pribadi yang terdaftar di KPP Pratama Padang). Jurnal Akuntansi, 2(1).

Ngadiman, N., \& Huslin, D. (2015). Pengaruh Sunset Policy, Tax Amnesty, Dan Sanksi Pajak Terhadap Kepatuhan Wajib Pajak (Studi Empiris di Kantor Pelayanan Pajak Pratama Jakarta Kembangan). Jurnal Akuntansi, 19(2), 225-241.

Nugroho, A. C. (2016). Tebusan Amnesti Pajak: Per 3 Oktober Rp97, 2 Triliun Deklarasi dan Repatriasi Rp.3.629 Triliun. Diunduh tanggal 7 Oktober 2016, http://finansial. bisnis.com/. 
AKRUAL: Jurnal Akuntansi, volume 9, nomor 2, April 2018 (142-156)

Peraturan Menteri Keuangan Nomor 118/PMK.03/2016 Pelaksanaan Undangundang Nomor 11 Tahun 2016 Tentang Pengampunan Pajak. Jakarta.

Pratiwi, R. (2016). Pengaruh Reinventing Policy, Tax Amnesty, Sanksi Pajak Dan Kepercayaan Terhadap Sistem Pemerintahanterhadap Kepatuhan Wajib Pajak Pada Kpp Pratama Semarang Tengah Dua (Doctoral Dissertation, Fakultas Ekonomi Unissula).

Ragimun. (2014). Analisis Implementasi Pengampunan Pajak (Tax amnesty) Di Indonesia. Diunduh tanggal 23 September 2016, http://www.kemenkeu.go.id/.

Rahayu, S. K., \& Suhayati, E. (2010). Auditing Konsep Dasar dan Pedoman Pemeriksaan Akuntan Publik. Yogyakarta: Graha Ilmu.

Undang-undang Republik Indonesia Nomor 11 Tahun 2016 Pengampunan Pajak. Lembaran Negara Republik Indonesia Tahun 2016 Nomor 131. Jakarta.

Sari, A. F. (2005). Analisis Kebijakan Pengampunan Pajak Dengan Penerimaan Negara. Skripsi. Universitas Indonesia.

Soewadji, J. (2012). Pengantar Metodologi Penulisan. Mitra Wacana Media. Jakarta.

Suandy, E. (2008). Perencanaan Pajak (Vol. Edisi 4). Jakarta: Salemba.

Waluyo \& W, B, Ilyas. (2001). Penyesuaian Dengan Ketentuan Peraturan Perundangundangan Perpajakan. Edisi Pertama. Salemba Empat. Jakarta.
Winerungan, O. L. (2013). Sosialisasi Perpajakan, Pelayanan Fiskus dan Sanksi Perpajakan Terhadap Kepatuhan WPOP Di KPP Manado dan KPP Bitung. Jurnal EMBA: Jurnal Riset Ekonomi, Manajemen, Bisnis dan Akuntansi, 1(3).

Wurianti, E. L. E., \& Subardjo, A. (2016). Analisis Faktor-Faktor yang mempengaruhi Kepatuhan Wajib Pajak di Wilayah KPP Pratama. Jurnal Ilmu dan Riset Akuntansi, 4(6).

Zahidah, C. (2010). Pengaruh tingkat, pemahaman, kepatuhan dan ketegasan sanksi perpajakan terhadap kewajiban perpajakan Pengusaha Usaha Kecil dan Menengah (UKM) di wilayah Jakarta Selatan. 